\title{
ISOLASI DAN IDENTIFIKASI BAKTERI AEROB YANG DAPAT MENYEBABKAN INFEKSI NOSOKOMIAL DI RUANGAN INSTALASI GIZI BLU RSUP PROF. DR. R. D. KANDOU MANADO
}

\author{
${ }^{1}$ Priska N. Riga \\ ${ }^{2}$ Velma Buntuan \\ ${ }^{2}$ Fredine Rares
}

\author{
${ }^{1}$ Kandidat Skripsi Fakultas Kedokteran Universitas Sam Ratulangi \\ 2,3 Bagian Mikrobiologi Fakultas Kedokteran Universitas Sam Ratulangi \\ E-mail: priskariga@yahoo.com
}

\begin{abstract}
Kitchen of hospital to be a part or unit of a hospital that is not less important as other services in the hospital , because it provides direct services to patients through the food served by nutritional care . Nosocomial infections are infections that occur during hospitalization where the infection does not exist at the time of admission to the hospital . Infections that occur more than 48 hours after hospital admission. Most infections occur in hospitals is caused by external factors, ie diseases which spread from food and cutlery . Implementation of the food was less qualified health care, in addition to extending the treatment process can also cause cross-infections or nosocomial infections which can be through the cutlery and food. Purpose: To determine the presence of aerobic bacteria that can cause nosocomial infections in the kitchen of BLU Prof. Dr R. D. Kandou Manado .Method: This study was a prospective descriptive study that analyzed 24 samples on cutlery and 6 samples of food in kitchen of BLU Nutrition Dr Prof. Dr R. D. Kandou Manado. Result: From the results of this study were found 11 species of bacteria such as Bacillus subtilis (33,3\%), a gram-negative cocci (10\%) , Lactobacillus (10\%), Enterobacter agglomerans (6,7\%), Serratia rubidaea (6,7\%), Providencia stuartii (3,3\%), Serratia liquefaciens (3,3\%), Providencia rettgeri (3,3\%), Vibrio cholera (3,3\%), Enterobacter cloacae (3,3\%), Enterobacter aerogenes (3,3\%).

Conclusion: The conclusion of this study showed that the most commonly found bacteria was Bacillus subtilis (33,3\%).
\end{abstract}

Keywords: nosocomial infection, kitchen of hospital, bacteria.

\begin{abstract}
Abstrak: Instalasi gizi menjadi bagian atau unit kerja di rumah sakit yang tidak kalah pentingnya dengan pelayanan lain di rumah sakit, karena memberikan pelayanan langsung kepada pasien melalui makanan yang disajikan oleh asuhan gizi. Infeksi nosokomial adalah infeksi yang terjadi selama perawatan di rumah sakit dimana infeksi tersebut tidak ada pada saat pasien masuk ke rumah sakit. Infeksi yang timbul lebih dari 48 jam setelah masuk rumah sakit. Kebanyakan infeksi yang terjadi di rumah sakit lebih disebabkan oleh faktor eksternal, yaitu penyakit yang penyebarannya ke makanan dan alat makan. Penyelenggaraan makanan yang kurang memenuhi syarat kesehatan, selain memperpanjang proses perawatan juga dapat menyebabkan timbulnya infeksi silang atau infeksi nosokomial yang diantaranya dapat melalui alat makan dan makanan. Tujuan: Untuk mengetahui adanya bakteri aerob yang dapat menyebabkan infeksi nosokomial di ruangan Instalasi Gizi BLU RSUP Prof. Dr. R. D. Kandou Manado. Metode penelitian: Penelitian ini merupakan penelitian deskriptif prospektif yang dianalisis secara desktriptif pada 24 sampel alat makan dan 6 sampel makanan di ruangan Instalasi Gizi BLU RSUP Prof. Dr. R. D. Kandou Manado. Hasil: Dari hasil
\end{abstract}


Riga, Buntuan, Rares: Isolasi dan identifikasi...

penelitian ditemukan 11 spesies bakteri yaitu Bacillus subtilis (33,3\%), Kokus gram negatif (10\%), Lactobacillus (10\%), Enterobacter agglomerans (6,7\%), Serratia rubidaea (6,7\%), Providencia stuartii (3,3\%), Serratia liquefaciens (3,3\%), Providencia rettgeri (3,3\%), Vibrio cholera (3,3\%), Enterobacter cloacae (3,3\%), Enterobacter aerogenes (3,3\%). Kesimpulan: Kesimpulan dari penelitian ini menunjukkan bahwa bakteri yang paling banyak ditemukan dalam penelitian ini adalah Bacillus subtilis (33,3\%).

Kata Kunci: infeksi nosokomial, instalasi gizi, bakteri.

Higiene dan sanitasi menjadi salah satu upaya pencegahan penyakit yang menitikberatkan pada usaha - usaha kesehatan lingkungan hidup manusia dan bagaimana cara orang memelihara dan melindungi diri agar tetap sehat. ${ }^{1}$ Higiene dan sanitasi sangat penting, terutama di tempat - tempat umum yang melayani orang banyak, ${ }^{2}$ salah satunya ruangan instalasi gizi rumah sakit yang menyediakan makanan bagi pasien. ${ }^{3}$

Instalasi gizi menjadi bagian atau unit kerja di rumah sakit yang tidak kalah pentingnya dengan pelayanan lain di rumah sakit, karena memberikan pelayanan langsung kepada pasien melalui makanan yang disajikan oleh asuhan gizi. ${ }^{4}$ Fasilitas ruangan instalasi gizi mempunyai peran yang penting dalam menunjang proses penyembuhan, karena itu fasilitas ruangan instalasi gizi harus memenuhi standar kebersihan. $^{3}$ Di dalam ruangan instalasi gizi Rumah Sakit Prof. Dr. R. D. Kandou Manado, terdapat makanan, petugas pengolah makanan, alat makan yang digunakan pasien, meja tempat makanan serta air pencucian peralatan masak dan makan. Beberapa tipe mikroorganisme dapat bertahan hidup dengan baik pada lingkungan seperti ini.

Mikroorganisme termasuk bakteri, virus, jamur dan parasit dapat menyebabkan infeksi nosokomial. Infeksi nosokomial adalah infeksi yang terjadi selama perawatan di rumah sakit dimana infeksi tersebut tidak ada pada saat pasien masuk ke rumah sakit. Infeksi yang timbul lebih dari 48 jam setelah masuk rumah sakit, biasanya sudah disebut infeksi nosokomial. Infeksi ini dapat disebabkan oleh mikroorganisme yang didapat dari orang lain (cross infection) atau disebabkan oleh flora normal dari pasien itu sendiri (endogenous infection). Kebanyakan infeksi yang terjadi di rumah sakit lebih disebabkan oleh faktor eksternal, yaitu penyakit yang penyebarannya ke makanan dan alat makan. ${ }^{5}$ Penyelenggaraan makanan yang kurang memenuhi syarat kesehatan, selain memperpanjang proses perawatan juga dapat menyebabkan timbulnya infeksi silang atau infeksi nosokomial yang diantaranya dapat melalui makanan. ${ }^{6}$

Prevalensi infeksi nosokomial pada 55 rumah sakit dari 14 negara yang berasal dari Eropa, Timur Tengah, Asia Tenggara dan Pasifik Barat sekitar 8,7\% dibandingkan dengan Asia Tenggara sebanyak 10,0\%. ${ }^{5}$ Di 10 RSU pendidikan Indonesia, infeksi nosokomial cukup tinggi yaitu 6-16\% dengan rata - rata 9,8\% pada tahun $2010{ }^{7}$

Penelitian yang dilakukan pada makanan dan peralatan makan di instalasi gizi RSUD Dr. Soedarso, yaitu bubur ratarata total mikrobanya $4.869 \mathrm{koloni} / \mathrm{gr}$, nasi $1.949 \mathrm{koloni} / \mathrm{g}$, tempat bubur 383.506,75 koloni $/ \mathrm{cm}^{2}$, tempat nasi 443.765,50 koloni $/ \mathrm{cm}^{2}$, sedangkan total mikroba pada sendok nasi 2.937,38 koloni $/ \mathrm{cm}^{2}$ dan sendok bubur 2.937,38 koloni/ $\mathrm{cm}^{2}{ }^{6}$

Pada penelitian di instalasi gizi Rumah Sakit Umum daerah Luwuk Kabupaten Banggai sebanyak 4 jenis sampel makanan yaitu ikan rebus, semur daging, kacang panjang tumis dan soto banjar positif terinfeksi e.coli. E.coli tertinggi pada ikan rebus dan kacang panjang tumis yaitu 37,2 sel/gr sampel makanan dan terendah adalah semur daging yaitu 4,5 sel/gr sampel makanan. ${ }^{8}$ 
Penelitian sebelumnya tentang usapan alat makan yang pernah dilakukan Sumura Ismayuri dkk sebelumnya, di dapatkan usapan alat makan positif mengandung E.coli. ${ }^{9}$

Berdasarkan deskripsi diatas dan mengingat pentingnya pengawasan terhadap kesehatan manusia maka penulis tertarik untuk melakukan penelitian selanjutnya yang berjudul “ Isolasi dan Identifikasi Bakteri Aerob yang Dapat Menyebabkan Infeksi Nosokomial di Ruangan Instalasi Gizi BLU RSUP Prof. Dr. R. D. Kandou Manado.“

\section{METODE PENELITIAN}

Penelitian yang dilakukan bersifat deskriptif prospektif. Penelitian ini dilakukan dari bulan November 2014 sampai Januari 2015. Sampel pada penelitian ini adalah 24 alat makan dan 6 makanan yang ada di ruangan Instalasi Gizi BLU RSUP Prof DR. R. D. Kandou Manado. Pengelolaan sampel dilakukan di Laboratorium Mikrobiologi Fakultas Kedokteran Universitas Sam Ratulangi Manado.

\section{HASIL PENELITIAN}

Ruang instalasi gizi harus dekat dengan instalasi rawat inap sehingga waktu pendistribusian makanan bisa merata untuk semua pasien. ${ }^{10}$ Pegawai di instalasi gizi BLU RSUP Prof. Dr. R. D. Kandou Manado berjumlah 24 orang. ${ }^{11}$

Berdasarkan hasil penelitian yang dilakukan di Instalasi Gizi BLU RSUP Prof. Dr. R. D. Kandou, yaitu penelitian infeksi nosokomial pada alat makan dan makanan sebanyak 30 sampel. Pengambilan sampel dapat diuraikan dalam tabel berikut.

Tabel 1. Uraian Pengambilan Sampel

\begin{tabular}{ccc}
\hline Kategori & Sampel & Jumlah sampel \\
\hline Alat makan & Piring & 24 \\
Makanan & $\begin{array}{c}\text { Ikan woku, sayur campur, } \\
\text { ikan goreng, tahu tempe, } \\
\text { telur rebus }\end{array}$ & 6 \\
\hline Total & & 30 \\
\hline
\end{tabular}

Keterangan: Tabel 1 menunjukkan sampel pada penelitian ini alat makan yaitu: piring dan makanan yaitu: ikan woku, sayur campur, ikan goreng, tahu tempe, telur rebus.

\section{Distribusi Sampel}

Distribusi sampel berdasarkan pertumbuhan bakteri pada media Nutrien Agar, Mac Conkey Agar, SS Agar. Dari 30 sampel yang diteliti, bakteri yang tumbuh pada Nutrien Agar sebanyak 24 sampel, pada Mac Conkey Agar sebanyak 11 sampel, SS Agar sebanyak 2 sampel.

a. Alat makan

Tabel 2. Distribusi Pertumbuhan Bakteri Pada Alat Makan

\begin{tabular}{lll}
\hline & Nutrien agar & $\begin{array}{l}\text { Mac } \\
\text { agar }\end{array}$ \\
\hline Ada pertumbuhan & 24 & 9 \\
Tidak ada pertumbuhan & - & 15 \\
\hline Total & 24 & 24 \\
\hline $\begin{array}{l}\text { Keterangan: Tabel 2 menunjukkan pertumbuhan bakteri sampel alat makan pada media nutrient } \\
\text { agar sebanyak 24 sampel, mac conkey agar sebanyak 9 sampel dan ada 15 sampel yang } \\
\text { tidak ada pertumbuhan pada media mac conkey agar. }\end{array}$
\end{tabular}


b. Makanan

Tabel 3. Distribusi Pertumbuhan Bakteri Pada Makanan

\begin{tabular}{ccc}
\hline Perbenihan & SS agar & Mac conkey agar \\
\hline Ada pertumbuhan & 2 & 2 \\
Tidak ada pertumbuhan & 4 & 4 \\
\hline Total & 6 & 6 \\
\hline $\begin{array}{l}\text { Keterangan: Tabel 3 menunjukkan pertumbuhan bakteri sampel makanan pada } \\
\text { media SS agar sebanyak 2 sampel, mac conkey agar sebanyak 2 sampel dan }\end{array}$ \\
ada 4 sampel yang tidak ada pertumbuhan pada media SS agar dan mac conkey agar.
\end{tabular}

\section{Hasil Pewarnaan Gram}

Penelitian ini dilakukan di Manado terhadap 30 sampel. Hal ini Laboratorium Mikrobilogi Fakultas disajikan dalam tabel 4.

Kedokteran Universitas Sam Ratulangi

a. Alat makan

Tabel 4. Hasil Pewarnaan Gram Pada Alat Makan

\begin{tabular}{ccc}
\hline Jenis bakteri & Jumlah sampel & Presentase (\%) \\
\hline Bakteri gram & 11 & 45,84 \\
positif & 9 & 37,5 \\
Bakteri gram negatif & 4 & 16,67 \\
Bakteri gram positif dan & 24 & 100 \\
\hline negatif & 24
\end{tabular}

Keterangan: Tabel 4 menunjukkan hasil pewarnaan gram pada sampel alat makan dimana bakteri gram positif (45,84\%), bakteri gram negatif $(37,5 \%)$ dan bakteri gram positif negatif $(16,67 \%)$.

a. Makanan

Tabel 5. Hasil Pewarnaan Gram Pada Makanan

\begin{tabular}{ccc}
\hline & Jumlah sampel & Presentase (\%) \\
\hline Bakteri gram positif & - & - \\
Bakteri gram negatif & 2 & 100 \\
Bakteri gram positif dan negatif & - & - \\
\hline Total & 2 & 100 \\
\hline
\end{tabular}

Keterangan: Tabel 5 menunjukkan hasil pewarnaan gram pada sampel makanan dimana bakteri gram negatif (100\%) dan tidak ada bakteri gram positif negatif.

\section{Distribusi Pertumbuhan Bakteri}

Hasil identifikasi bakteri dapat dilihat pada tabel 6. Tabel 6 menunjukkan total bakteri yang didapat adalah 26 bakteri terdiri dari 10 spesies yaitu Bacillus subtilis terbanyak ditemukan yaitu 10 sampel (33,3\%), Kokus gram negatif ditemukan sebanyak 3 sampel (10\%), Lactobacillus ditemukan sebanyak
3 sampel (10\%), Enterobacter agglomerans ditemukan sebanyak 2 sampel (6,7\%), Serratia rubidaea ditemukan sebanyak 2 sampel (6,7\%), Providencia stuartii ditemukan sebanyak 1 sampel (3,3\%), Serratia liquefaciens ditemukan sebanyak 1 sampel (3,3\%), Providencia rettgeri ditemukan sebanyak 1 sampel (3,3\%), Vibrio cholera 
ditemukan sebanyak 1 sampel (3,3\%), Enterobacter cloacae ditemukan sebanyak 1 sampel (3,3\%), Enterobacter aerogenes ditemukan sebanyak 1 sampel (3,3\%), dan ada sebanyak 4 sampel
(13,3\%) yang tidak tumbuh pada media pertumbuhan.

Hasil distribusi bakteri juga dapat diuraikan berdasarkan kategori sampel pada tabel 7 .

Tabel 6. Hasil Distibusi Bakteri

\begin{tabular}{ccc}
\hline Bakteri & Jumlah sampel & Presentase (\%) \\
\hline Bacillus subtilis & 10 & 33,3 \\
Kokus gram negatif & 3 & 10 \\
Lactobacillus & 3 & 10 \\
Enterobacter agglomerans & 2 & 6,7 \\
Serratia rubidaea & 2 & 6,7 \\
Providencia stuartii & 1 & 3,3 \\
Serratia liquefaciens & 1 & 3,3 \\
Providencia rettgeri & 1 & 3,3 \\
Vibrio cholerae & 1 & 3,3 \\
Enterobacter cloacae & 1 & 3,3 \\
Enterobacter aerogenes & 1 & 3,3 \\
Tidak ada bakteri & 4 & 13,3 \\
\hline Total & 30 & 100
\end{tabular}

Keterangan: Tabel 6 menunjukkan total bakteri yang didapat sebanyak 26 bakteri terdiri dari 10 spesies bakteri yaitu Bacillus subtilis (33,3\%), Kokus gram negatif (10\%), Lactobacillus (10\%), Enterobacter agglomerans (6,7\%), Serratia rubidaea (6,7\%), Providencia stuartii (3,3\%), Serratia liquefaciens (3,3\%), Providencia rettgeri (3,3\%), Vibrio cholera (3,3\%), Enterobacter cloacae (3,3\%), Enterobacter aerogenes (3,3\%).

Dari hasil uraian kategori menurut alat makan terdiri dari Bacillus subtilis ditemukan sebanyak 10 sampel (41,7\%), Kokus gram negatif ditemukan sebanyak 3 sampel (12,5\%), Lactobacillus ditemukan sebanyak 3 sampel (12,5\%), Enterobacter agglomerans ditemukan sebanyak 2 sampel (8,3\%), Serratia rubidaea ditemukan sebanyak 2 sampel (8,3\%), Providencia stuartii ditemukan sebanyak 1 sampel (4,17\%), Serratia liquefaciens ditemukan sebanyak 1 sampel (4,17\%), Providencia rettgeri ditemukan sebanyak 1 sampel (4,17\%), Vibrio cholera ditemukan sebanyak 1 sampel (4,17\%).

\section{BAHASAN}

Dalam periode November 2014 Januari 2015, telah diteliti sampel berupa alat makan dan makanan di Instalasi gizi RSUP Prof. DR. R. D. Kandou Manado sebanyak masing- masing 24 sampel alat makan dan 6 sampel makanan, dan dilakukan pemeriksaan di Laboratorium
Mikrobiologi Fakultas Kedokteran Universitas Sam Ratulangi Manado.

Berdasarkan hasil yang didapatkan, pada penelitian dari 24 sampel alat makan, bakteri yang tumbuh pada Nutrien Agar sebanyak 24 sampel (100\%), dan bakteri yang tumbuh pada MacConkey Agar sebanyak 9 sampel (37,5\%), sedangkan 
hasil yang didapatkan pada penelitian dari 6 sampel makanan, bakteri yang tumbuh pada SS Agar sebanyak 2 sampel
(33,4\%), dan yang tumbuh pada MacConkey Agar sebanyak 2 sampel $(33,4 \%)$.

a. Alat makan

Tabel 7. Hasil Distribusi Bakteri Pada Alat Makan

\begin{tabular}{ccc}
\hline Bakteri & Jumlah sampel & Presentase (\%) \\
\hline Bacillus subtilis & 10 & 41,7 \\
Kokus gram negatif & 3 & 12,5 \\
Lactobacillus & 3 & 12,5 \\
Enterobacter agglomerans & 2 & 8,3 \\
Serratia rubidaea & 2 & 8,3 \\
Providencia stuartii & 1 & 4,17 \\
Serratia liquefaciens & 1 & 4,17 \\
Providencia rettgeri & 1 & 4,17 \\
Vibrio cholerae & 1 & 4,17 \\
\hline Total & 24 & 100
\end{tabular}

Keterangan: Tabel 7 menunjukkan total bakteri pada alat makan terdiri dari 10 spesies bakteri yaitu Bacillus subtilis (41,7\%), Kokus gram negatif (12,5\%), Lactobacillus (12,5\%), Enterobacter agglomerans (8,3\%), Serratia rubidaea (8,3\%), Providencia stuartii (4,17\%), Serratia liquefaciens (4,17\%), Providencia rettgeri (4,17\%), Vibrio cholera (4,17\%).

b. Makanan

Tabel 8. Hasil Distribusi Bakteri Pada Makanan

\begin{tabular}{ccc}
\hline Bakteri & $\begin{array}{c}\text { Jumlah } \\
\text { sampel }\end{array}$ & $\begin{array}{c}\text { Presentase } \\
\text { (\%) }\end{array}$ \\
\hline $\begin{array}{c}\text { Enterobacter } \\
\text { cloacae }\end{array}$ & 1 & 16,67 \\
$\begin{array}{c}\text { Enterobacter } \\
\text { aerogenes } \\
\text { Tidak ada } \\
\text { bakteri }\end{array}$ & 1 & 16,67 \\
\hline Total & 4 & 66,67 \\
\hline
\end{tabular}

Keterangan: Tabel 8 menunjukkan total bakteri pada makanan terdiri dari Enterobacter cloacae sampel (16,67\%), Enterobacter aerogenes (16,67\%) dan ada sebanyak 4 sampel $(66,67 \%)$ yang tidak tumbuh pada media pertumbuhan.

Dari hasil uraian kategori menurut makanan terdiri dari Enterobacter cloacae ditemukan sebanyak 1 sampel (16,67\%), Enterobacter aerogenes ditemukan sebanyak 1 sampel (16,67\%), dan ada sebanyak 4 sampel (66,67\%) yang tidak tumbuh pada media pertumbuhan.

Hasil koloni bakteri yang tumbuh selanjutnya dilakukan pewarnaan gram dan selanjutnya dilakukan dengan identifikasi dengan uji biokimia. Hasil identifikasi bakteri ditemukan 11 spesies bakteri yaitu Bacillus subtilis, Kokus gram negatif,
Lactobacillus, Enterobacter agglomerans, Serratia rubidaea, Providencia stuartii, Serratia liquefaciens, Providencia rettgeri, Vibrio cholerae, Enterobacter cloacae, Enterobacter aerogenes.

Bakteri yang ditemukan di alat makan terdiri dari Bacillus subtilis ditemukan sebanyak 10 sampel (41,7\%), Kokus gram negatif ditemukan sebanyak 3 sampel (12,5\%), Lactobacillus ditemukan sebanyak 3 sampel (12,5\%), Enterobacter agglomerans ditemukan sebanyak 2 sampel (8,3\%), Serratia rubidaea ditemukan 
sebanyak 2 sampel (8,3\%), Providencia stuartii ditemukan sebanyak 1 sampel (4,17\%), Serratia liquefaciens ditemukan sebanyak 1 sampel (4,17\%), Providencia rettgeri ditemukan sebanyak 1 sampel (4,17\%), Vibrio cholera ditemukan sebanyak 1 sampel (4,17\%). Sedangkan bakteri yang ditemukan di makanan terdiri dari Enterobacter cloacae ditemukan sebanyak 1 sampel (16,67\%), Enterobacter aerogenes ditemukan sebanyak 1 sampel (16,67\%), dan ada sebanyak 4 sampel (66,67\%) yang tidak tumbuh pada media pertumbuhan.

Berdasarkan tabel 6 didapatkan kuman tersering yang didapatkan pada penelitian ini adalah Bacillus subtilis sebanyak 10 sampel, bakteri Bacillus subtilis merupakan organisme saprofit yang lazim terdapat dalam tanah, air, udara dan sayuran. Bacillus subtilis adalah bakteri pembentuk endospora, endospora yang terbentuk memungkinkan untuk menahan suhu ekstrim serta lingkungan yang kering. Bakteri Bacillus subtilis merupakan bakteri non-patogenik. Bakteri ini dapat mencemari makanan, namun jarang menyebabkan keracunan makanan. ${ }^{12,13}$

Hasil penelitian ini, menemukan jenis bakteri yang sama dengan yang ditemukan oleh Ekrami et al menyatakan bahwa penelitian yang dilakukan di instalasi gizi rumah sakit di Iran didapatkan sejumlah besar bakteri berupa: Staphylococcus aureus, Klebsiella pneumonia, E.coli, Enterobacter spp, Pseudomonas aeruginosa, Enterococcus spp, Proteus spp, Acinetobacter spp, Bacillus spp. ${ }^{14}$ Dimana peneliti mendapatkan bakteri bacillus subtilis yang terbanyak pada alat makan.

Selanjutnya kuman yang ditemukan dalam penelitian ini adalah Kokus gram negatif sebanyak 3 sampel. Bakteri ini adalah kelompok kokus kecil, gram-negatif dan merupakan bagian dari flora normal mulut, nasofaring dan mungkin usus. Kadang-kadang spesies ini diisolasi dari infeksi polimikroba anaerob. Spesies ini jarang menjadi satu-satunya penyebab infeksi. $^{12}$ Tidak dilanjutkan penelitian untuk uji biokomia pada bakteri ini. Berikutnya bakteri Lactobacillus ditemukan sebanyak 3 sampel. Bakteri ini umumnya berhubungan dengan sistem pencernaan manusia dan hewan. Normalnya bakteri ini adalah mikroflora sistem pencernaan, yang berfungsi sebagai imunomodulasi, menghambat pertumbuhan bakteri patogen dan mempertahankan mikroflora sistem pencernaan normal. ${ }^{15}$

Berikutnya bakteri Enterobacter agglomerans ditemukan sebanyak 2 sampel. Agglomerans pantoea (sebelumnya Enterobacter agglomerans) adalah kuman gram negatif, tidak berspora dan termasuk dalam famili Enterobacteriaceae. Bakteri ini banyak ditemukan di air, tanah, limbah, sayuran dan bahan makanan. Bakteri ini adalah patogen pada hewan dan manusia. $P$. agglomerans dikenal sebagai patogen tanaman. Pada pertengahan tahun 1960-an, bakteri ini diidentifikasi sebagai kuman penyebab infeksi nosokomial. ${ }^{16}$

Selain itu pada penelitian ini juga ditemukan bakteri Serratia rubidaea sebanyak 2 sampel dan Serratia liquefaciens sebanyak 1 sampel. Serratia spp merupakan bakteri batang gram negatif, bakteri ini ditemukan di permukaan tanah, air dan tanaman. Serratia spp termasuk dalam famili Enterobacteriaceae. Bakteri ini merupakan bakteri patogen oportunistik dan dapat menyebabkan infeksi termasuk bakterimia, pneumonia, gastroenteritis. Sampai saat ini, sebagian besar Serratia spp dianggap sebagai patogen infeksi nosokomial. ${ }^{17}$

Hasil penelitian yang ditemukan Cairo Romilda C et al menyatakan bahwa penelitian yang dilakukan di instalasi gizi rumah sakit anak di Brazil menemukan bakteri Serratia spp pada tangan pegawai instalasi gizi. ${ }^{18}$ Berbeda dengan hasil yang didapatkan peneliti bahwa bakteri Serratia spp ditemukan di alat makan. Bakteri Serratia spp dapat mengkontaminasi alat makan melalui tangan pegawai instalasi gizi yang kurang higiene, dimana 
kebersihan penjamah atau pengolah makanan merupakan faktor penting agar tidak terjadi kontaminasi pada makanan yang akan ditangani. Prosedur penting untuk penjamah atau pengolah makanan adalah pencucian tangan, kebersihan dan kesehatan diri. ${ }^{19}$

Providencia stuartii dan Providencia rettgeri masing-masing ditemukan sebanyak 1 sampel dari 30 sampel. Providencia sp merupakan bakteri batang gram negatif dan merupakan bakteri flora normal usus. Semua organisme tersebut dapat menimbulkan infeksi saluran kemih dan kadang-kadang infeksi lain seperti gastroenteritis dan bakterimia. Infeksi yang diakibatkan oleh Providencia sp jarang terjadi dan bakteri ini dapat menyebabkan infeksi nosokomial. ${ }^{12,20}$

Hasil penelitian yang ditemukan Synder Peter menyatakan bahwa penelitian yang dilakukan di rumah sakit di Minnesota menemukan bakteri Providencia $s p$ pada tangan tangan pegawai rumah sakit. $^{21}$ Berbeda dengan hasil yang didapatkan peneliti bahwa bakteri Providencia sp ditemukan di alat makan. Bakteri ini dapat mengkontaminasi alat makan melalui tangan pegawai yang kurang higiene. Kontaminasi ini dapat menjadi rantai penyakit.

Vibrio cholerae adalah bakteri batang gram negatif. Dalam kondisi yang normal, $V$. cholerae bersifat patogenik hanya pada manusia. V.cholerae dapat menyebabkan kolera pada manusia, sementara vibrio lainnya dapat menyebabkan sepsis atau enteritis. Organisme ini tidak memasuki aliran darah tetapi tetap di dalam usus. Organisme $V$. cholerae yang virulen menempel pada mikrovili brush border sel epitel. Di tempat ini mereka berkembang biak dan mengeluarkan toksin kolera. ${ }^{12}$

Kuman lainnya yang ditemukan dalam penelitian ini adalah Enterobacter cloacae dan Enterobacter aerogenes. Enterobacter cloacae didapatkan sebanyak 1 sampel dan Enterobacter aerogenes didapatkan sebanyak 1 sampel. Enterobacter sp ditemukan di kulit manusia, tanah, air dan limbah. Enterobacter sp khususnya Enterobacter cloacae dan Enterobacter aerogenes merupakan patogen penyebab infeksi nosokomial dan bertanggung jawab untuk berbagai infeksi diantaranya, infeksi saluran pernafasan, infeksi saluran kemih, sepsis, infeksi intraabdominal, infeksi kulit dan jaringan lunak, infeksi mata dan infeksi saluran pencernaan. Meskipun infeksi Enterobacter yang didapatkan di lingkungan sering dilaporkan, tetapi infeksi Enterobacter nosokomial jauh lebih sering. 22. Organisme ini jarang menyebabkan penyakit pada orang sehat. Kuman patogen oportunistik ini mirip dengan anggota lain dalam famili Enterobacteriaceae. Sumber infeksi dapat melalui kulit, saluran pencernaan atau saluran kemih. Beberapa laporan dicurigai berasal dari tangan perawat, endoskopi dan stetoskop. Laporan sebelumnya dari National Nosocomial Infections Surveillance System (NNIS) bahwa Enterobacter sp menyebabkan $11,2 \%$ kasus pneumonia di semua jenis ICU yang merupakan peringkat ketiga setelah Staphylococcus aureus (18,1\%) dan P. aeruginosa $(17 \%){ }^{22}$

Hasil ditemukan oleh Ekrami et al menyatakan bahwa penelitian yang dilakukan di instalasi gizi rumah sakit di Iran pada cucian piring, troli pengangkut makanan, permukaan meja persiapan makanan, penggiling daging didapatkan bakteri Enterobacter spp. ${ }^{14}$ Berbeda dengan hasil yang didapatkan peneliti bahwa bakteri Enterobacter spp ditemukan di makanan.

Penelitian yang dilakukan oleh Husain dan Albasar MI di instalasi gizi rumah sakit umum daerah Luwuk kabupaten Banggai menemukan bakteri E.coli positif pada beberapa sampel makanan. ${ }^{8}$

Penyelenggaraan makanan di rumah sakit dengan tujuan utama untuk memenuhi kebutuhan nutrisi pasien agar dapat mempercepat penyembuhan penyakitnya, maka perlu adanya upaya penyehatan makanan berupa pengendalian faktor yang memungkinkan terjadinya kontaminasi pada makanan yang akan disajikan, 
sehingga makanan pun dapat berfungsi ganda yakni selain berfungsi untuk memenuhi zat-zat gizi tubuh, juga dapat berfungsi sebagai obat untuk mempercepat penyembuhan penyakit pada pasien yang dirawat di rumah sakit. Rumah sakit merupakan salah satu tempat umum yang memberikan pelayanan kesehatan masyarakat dengan inti pelayanan medis. ${ }^{8}$

Salah satu sarana penunjang kegiatan pelayanan medis yang sangat penting adalah instalasi gizi. Sarana instalasi gizi rumah sakit berperan penting dalam penyelenggaraan makanan rumah sakit oleh karena tugas dan fungsinya sangat sentral dalam penyembuhan pasien. Pemenuhan zat gizi pasien belum menjamin seseorang akan cepat sembuh, manakala makanan tersebut terkontaminasi oleh bahan berbahaya dan bakteri yang mematikan. Terjadinya kontaminasi dapat terjadi selama tahapan pengelolaan makanan mulai dari pemilihan bahan, penyimpanan bahan makanan, pengolahan makanan, penyimpanan makanan, pengangkutan dan penyajian makanan contohnya tercemarnya bahan baku, kebersihan peralatan masak dan makan, food handler, air pencuci peralatan, dan serangga serta binatang penganggu sebagai vektor penyakit. ${ }^{8}$

\section{SIMPULAN}

Berdasarkan hasil penelitian isolasi dan identifikasi bakteri aerob yang dapat menyebabkan infeksi nosokomial di ruangan instalasi gizi BLU RSUP Prof. DR. R. D. Kandou Manado, maka dapat disimpulkan bahwa jumlah bakteri yang didapat dari 30 sampel sebanyak 11 bakteri. Bakteri yang paling banyak pada pemeriksaan ini yaitu Bacillus subtilis (33,3\%), Kokus gram negatif ditemukan sebanyak 3 sampel (10\%), Lactobacillus ditemukan sebanyak 3 sampel (10\%), Enterobacter agglomerans ditemukan sebanyak 2 sampel (6,7\%), Serratia rubidaea ditemukan sebanyak 2 sampel (6,7\%), Providencia stuartii ditemukan sebanyak 1 sampel (3,3\%), Serratia liquefaciens ditemukan sebanyak 1 sampel (3,3\%), Providencia rettgeri ditemukan sebanyak 1 sampel (3,3\%), Vibrio cholera ditemukan sebanyak 1 sampel (3,3\%), Enterobacter cloacae ditemukan sebanyak 1 sampel (3,3\%), Enterobacter aerogenes ditemukan sebanyak 1 sampel (3,3\%), dan ada sebanyak 4 sampel (13,3\%) yang tidak tumbuh pada media pertumbuhan.

\section{DAFTAR PUSTAKA}

1. Bapelkes Cikarang. Enam Prinsip Sanitasi Makanan Dalam Pengelolaannya. 2012 Aug 11 [cited 2014 September 17]. Available from:

http://www.bapelkescikarang.or.id/inde x.php?option=com_content\&view=arti cle\&id=548:enam-prinsip-sanitasimakanan-dalampengelolaannya\&catid=39:kesehatan\&I temid $=15$

2. Djarismawati, Sukana B, Sugiharti. Pengetahuan Dan Perilaku Penjamah Tentang Sanitasi Pengolahan Makanan Pada Instalasi Gizi Rumah Sakit Di Jakarta. Media Litbang Kesehatan. 2004;24:31.

3. Nurmianto E, Wessiani NA, Aprilia B, Lukitawati L, Siswanto B. Peningkatan kenyamanan staf Rumah Sakit melalui studi desain tata letak dapur yang ergonomis. Jurnal Teknik dan Manajemen Industri. 2011;6:87

4. RSUD Dr. M. Ashari Pemalang. Instalasi Gizi. [cited 2014 September 23]. Available from: http://rsud.pemalangkab.go.id/fasilitaspenunjang-rsud-6.html

5. Ducel G, Fabry J, Nicolle L. Prevention of hospital - acquired infections. World Health Organization. 2002;12:1,4,52

6. Nurlaela E. Keamanan Pangan Dan Perilaku Penjamah Makanan Di Instalasi Gizi Rumah Sakit. Media Gizi Masyarakat Indonesia. 2011;1:1-3

7. Nugraheni R, Suhartono, Winarni S. Infeksi nosokomial di RSUD Setjonegoro Kabupaten Wonosobo. Media Kesehatan Masyarakat Indonesia. 2012;11:95

8. RSU Luwuk Banggai. www.untika.ac.id tahun 2011. 
9. Sumira I, Endriani R, Chandra F. Gambaran Higiene Sanitasi dan Pemerikasaan Bakteriologis Pada Peralatan Makan Di Instalasi Gizi RS $\mathrm{X}$.

10.Kementrian Kesehatan RI. Seri Perencanaan Pedoman Teknis Saran dan Prasarana Rumah Sakit Kelas B. Jakarta. 2010

11.RSU Prof. Dr. R. D. Kandou Manado. 2014 Juni. [cited 2015 Jan 22]. Available from: http://rumahsakit.findthebest.co.id/1/965/RSU-ProfDr-R-D-Kandou-Manado.

12.Brooks GF, Butel JS, Morse SA. Jawetz, Melnick, \& Adelberg. Mikrobiologi Kedokteran. Edisi ke-23. Jakarta: EGC. 2007

13.Microbewiki. Bacillus subtilis. 2013 Maret. [cited 2015 Jan 17]. Available from: http://microbewiki.kenyon.edu/index.p hp/Bacillus_subtilis

14.Ekrami A, Kayedani A, Jahangir M, Kalantar E, Jalali M. Isolation of common aerobic bacterial pathogens from the environment of seven hospitals, Ahvaz, Iran. Jundishapur Journal of Microbiology. 2011;4(2): 79.

15. Microbewiki. Lactobacillus. 2010 Agustus. [cited 2015 Jan 17]. Available from: http://microbewiki.kenyon.edu/index.p $\mathrm{hp} /$ Lactobacillus

16.Mardaneh J, Dallal Mohammad MS. Isolation, identification and antimicrobial susceptibility of Pantoea (Enterobacter) agglomerans isolated from consumed powdered infant formula milk (PIF) in NICU ward: First report from Iran. Iran $\mathrm{J}$ Microbiol. 2013;5(3): 263-267.

17.Public Health Agency of Canada. Serratia spp. 2012 April. [cited 2015 Jan 17]. Available from: http://www.phacaspc.gc.ca/lab-bio/res/psdsftss/serratia-spp-eng.php

18.Cairo Romilde, Silvia L, Andrade C, Santos kleber, antos D, et al. Bacterial contamination in milk kitchen in pediatric hospital in Salvador, Brazil. Braz J Infect Dis/ 2008;12(3).

19.Fatmawati S, Rosidi A, Handarsari E. Perilaku higiene pengolah makanan berdasarkan pengetahuan tentang higiene mengolah makanan dalam penyelenggraan makanan di pusat pendidikan dan latihan olahraga pelajar jawa tengah. Jurnal gizi Universitas Muhammadiyah Semarang. 2013;2(2) 30-31

20.Hawley-Molloy JS. Providencia Infection. Medscape. 2014 Sep. [cited 2015 Jan 17]. Available from: http://emedicine.medscape.com/article/ 226541-overview

21.Snyder P. A "safe hands" hand wash program for retail food operations. 2014. [cited 2015 Jan 28]. Available from: http://www.sproutnet.com/SafeHands

22.Fraser SL. Enterobacter Infection. Medscape. 2014 Maret. [cited 2015 Jan 17]. Available from: http://emedicine.medscape.com/article/ 216845-overview\#a0156. 